\title{
ANALISA DAN PERANCANGAN SISTEM INFORMASI AKADEMIK BERBASIS WEB PADA MI AL-MURSYIDIYYAH AL-'ASYIROTUSSYAFI'IYYAH
}

\author{
Khaerul Anam ${ }^{1}$, Asep Taufik Muharram² \\ ${ }^{1,2}$ Prodi Teknik Informatika \\ UNIVERSITAS PAMULANG \\ Khaerulanam124@gmail.com, taufikmuharram@gmail.com
}

\begin{abstract}
ABSTRAK
Perkembangan Teknologi dalam era globalisasi saat ini melaju dengan sangat pesat dan informasi yang beredar semakin banyak dan kompleks sehingga dunia pendidikan harus dapat mengikuti perkembangan teknologi terutama dalam bidang teknologi komputer, Seiring dengan perkembangan teknologi saat ini. Kebutuhan manusia akan informasi pada saat ini menjadi begitu mudah terpenuhi dengan hadirnya internet, yang memungkinkan melakukan transfer informasi hanya dengan hitungan detik.Namun seiring dengan kemajuan teknologi ditambah dengan meningkatnya gaya hidup mobile. Proses pemantauan nilai akademik siswa pada sistem yang sedang berjalan pada MI Al-Mursyidiyyah Al-'Asyirotussyafi' iyyah dilakukan dengan cara yang konvesional, dimana siswa dan wali siswa hanya bisa melihat hasil dari kemampuan siswa tersebut pada akhir masa pembelajaran atau yang kita kenal dengan istilah pembagian raport siswa.Untuk membantu pihak sekolah dan orang tua atau wali siswa dalam memantau nilai akademik siswa MI Al-Mursyidiyyah Al-'Asyirotussyafi'iyyah - Pamulang, melalui sebuah aplikasi berbasis web dan diharapkan aplikasi ini dapat memberikan informasi kepada pihak sekolah dan orang tua secara efektif dan efisien yang berkaitan dengan penilaian akademik siswa.Metode yang di gunakan dalam melakukan pengembangan sistem aplikasi yaitu SDLC (System Development Life Cycle) dengan model proses waterfall, Dengan sistem yang dijalankan diharapkan akan meminimalisir kesalahan yang tidak diperlukan dalam pembuatan dan pelaporan nilai siswa.
\end{abstract}

Kata Kunci: Sistem Informasi Akademik \& Nilai dan Laporan.

\begin{abstract}
Technological developments in the current era of globalization drove very rapidly and information circulating more and more complex and so the world of education must be able to follow the development of technology, especially in the field of computer technology, Along with the development of technology today. The human need for information at this time becomes so easily fulfilled by the presence of the internet, which allows the transfer of information in just a matter of seconds. But along with technological advancements coupled with increasing mobile lifestyle. The process of monitoring the academic value of students on the system that is running on MI AlMursyidiyyah Al-'Asyirotussyafi'iyyah done in a conventional way, where students and guardians can only see the results of the student's ability at the end of the learning period or that we are familiar with the term division of student report cards. To assist the school and parents or guardians in monitoring the academic value of MI Al-Mursyidiyyah Al-'Asyirotussyafi'iyyah Pamulang students, through a web-based application and hopefully this application can provide information to the school and parents effectively and efficiently relating to students' academic assessment. The method used in the development of application system is SDLC (System Development Life Cycle) with waterfall process model, With the system executed is expected to minimize errors that are not required in making and reporting student value.
\end{abstract}

Keywords: Academic Information System \& Values and Reports.

http://dx.doi.org/10.15408/jti.v11i2.8867 
http://dx.doi.org/10.15408/jti.v11i2.8867

\section{PENDAHULUAN}

Perkembangan Teknologi dalam era globalisasi saat ini melaju dengan sangat pesat dan informasi yang beredar semakin banyak dan kompleks sehingga dunia pendidikan harus dapat mengikuti perkembangan teknologi terutama dalam bidang teknologi komputer, Seiring dengan perkembangan teknologi saat ini. Kebutuhan manusia akan informasi pada saat ini menjadi begitu mudah terpenuhi dengan hadirnya internet, yang memungkinkan melakukan transfer informasi hanya dengan hitungan detik.

\section{Al-Mursyidiyyah}

Al'Asyirotussyafi'iyyah merupakan lembaga pendidikan yang bertugas menangani kegiatankegiatan yang berkaitan dengan pendidikan, tujuan utama seperti yang kita ketahui untuk mencerdaskan kehidupan bangsa. Pendidikan juga merupakan modal utama bagi suatu bangsa dalam upaya meningkatkan kualitas sumber daya manusia yang dimilikinya.

Untuk menghasilkan kualitas sumber daya manusia yang handal harus didukung oleh kualitas sarana dan prasarana pendidikan, karena sarana dan prasarana merupakan salah satu faktor penting dalam menunjang belajar siswa dan memberikan kenyamanan dalam proses belajar mengajar.

Menurut Nurcahyo (2008 : 56). Sebuah lembaga pendidikan tidak lepas dengan kurikulum yang tugasnya adalah menangani maupun mengawasi yang berkaitan dengan fasilitas sarana dan prasarana pendidikan yang dibutuhkan oleh sekolah guna menunjang lancarnya proses belajar mengajar.

Sistem ini dirasa kurang optimal untuk pemantau kemampuan siswa secara keseluruhan, karena sistem ini hanya memberikan hasil akhir dari segala aktivitas belajar yang dijalani oleh seorang siswa, sehingga proses-proses pembelajaran yang dijalani seorang siswa dari hari ke hari tidak terpantau.

Berdasarkan penelitian sejenis dari Toni Alimin, dalam penelitian tentang Sistem Informasi Nilai Siswa di MI Mumtaza Islamic School Pondok Cabe, Dalam penelitian tersebut disebutkan bahwa pengecekan nilai siswa masih bersifat paper base atau menggunakan kertas secara manual. Guru mengisikan keterangan nilai pada kertas, yang nantinya akan diberikan kepada staf Tata Usaha (TU) yang kemudian akan direkap tiap semester untuk ditulis di buku rapor siswa tiap semester. Cara ini sangatlah rentan dari berbagai macam kesalahan baik kesalahan teknis (technical error), maupun kesalahan manusia (human error). Kesalahan - kesalahan ini akan menyebabkan hilangya berkas ataupun rusak. Dan lebih jauh lagi akan mempengaruhi proses penilaian peserta didik. Maka dari itu Toni Alimin membuat sistem informasi pengolahan nilai ini bertujuan untuk mempermudah pengecekan dan pencatatan laporan data nilai siswa yang terkomputerisasi. Sistem yang dibuat adalah Sistem Informasi pengolahan nilai berbasis web dan MySQL sebagai databasenya. Metode yang digunakan menggunakan SDLC (System Development Life Cycle) dengan model proses waterfall. Dalam Sistem Informasi pengolahan nilai berbasis web terdapat sistem validasi yang berguna untuk menghindari kesalahan-kesalahan. yang terjadi dengan menggunakan cara ujian dengan paper base.

\section{TINJAUAN PUSTAKA}

Secara umum, sistem dapat diartikan sebagai kumpulan dari elemen-elemen yang berinteraksi untuk mencapai tujuan tertentu sebagai satu kesatuan. Menurut Jerry Fith Gerald (Jogiyanto, 2005 : 49), sistem adalah suatu jaringan kerja dari prosedur-prosedur yang saling berhubungan, berkumpul bersama-sama untuk melakukan suatu kegiatan atau menyelesaikan suatu sasaran tertentu. Dalam mendefinisikan pengertian sistem, Gerald lebih menekankan pada urutan-urutan operasi di dalam sistem. Mulyanto (2009: 28).

Model umum sebuah sistem adalah input, process dan output. Hal ini merupakan konsep sebuah sistem yang sederhana, sebab sebuah sistem dapat mempunyai beberapa masukan dan keluaran. Selain itu pula sistem memiliki karakteristik atau sifat-sifat tertentu, yang mencirikan bahwa hal tersebut bisa dikatakan sebagai suatu sistem.

Nilai suatu informasi berhubungan dengan keputusan. Keputusan dapat berkisar dari keputusan berulang yang sederhana sampai keputusan strategis jangka panjang informasi tersebut. Informasi yang dapat mengurangi ketidakpastian dalam pengambilan keputusan 
dapat dikatakan informasi tersebut memiliki nilai yang tinggi. Sebaliknya apabila informasi tersebut kurang memberikan manfaat dalam pengambilan keputusan, maka informasi tersebut dikatakan bernilai rendah. (Mulyanto, 2009).

Sistem Informasi Akademik merupakan sistem yangmengolah data dan melakukan proses kegiatan akademik yang melibatkan antara siswa, guru, administrasi akademik, penilaian dan data atribut lainnya. Sistem informasi akademik melakukan kegiatan administrasi akademik, melakukan proses-proses transaksi belajarmengajar antara guru dan siswa, melakukan proses administrasi akademik yang baik menyangkut kelengkapan dokumen dan biaya yang muncul pada kegiatan registrasi ataupun kegiatan operasional harian administrasi akademik. (Jamilah, 2011).

\section{METODOLOGI}

Metode yang penulis gunakan dalam melakukan pengembangan sistem aplikasi yaitu SDLC (System Development Life Cycle) dengan model proses waterfall, Prahasta, (2000: 223). Dalam model ini terdapat beberapa tahapan pengembangan sistem, yang dapat diuraikan sebagai berikut :

a. Perencanaan

Yaitu mengumpulkan kebutuhan pada tingkat sistem, tingkat bisnis strategis dan tingkat area bisnis, seperti melakukan feasibility study, alokasi waktu, dan menentukan cakupan aplikasi sistem informasi pemantauan perkembangan siswa

b. Analisis (analysis)

Yaitu membuat analisis workflow manajemen sistem yang sedang berjalan.

c. Perancangan (design)

Yaitu membuat desain workflow manajemen dan desain sistem yang diperlukan untuk pengembangan sistem informasi yang diusulkan.

d. Pemrograman (Coding)

Tahap ini sering disebut juga sebagai tahap implementasi perangkat lunak atau coding. Dengan kata lain, pada tahap ini dilakukan implementasi hasil rancangan ke dalam barisbaris kode program yang dapat dimengerti oleh mesin (komputer).

e. Implementasi (Implementation)

Yaitu menerapkan sistem informasi yang telah dibuat untuk digunakan user. f. Pengoperasian dan Pemeliharaan (operation and maintenance)

Yaitu kegiatan untuk mendukung beroperasinya aplikasi sistem informasi.

\section{HASIL DAN PEMBAHASAN}

\subsection{Penelitian Terkait}

Berdasarkan penelitian sejenis dari Toni Alimin, dalam penelitian tentang Sistem Informasi Nilai Siswa di MI Mumtaza Islamic School Pondok Cabe, Dalam penelitian tersebut disebutkan bahwa pengecekan nilai siswa masih bersifat paper base atau menggunakan kertas secara manual. Guru mengisikan keterangan nilai pada kertas, yang nantinya akan diberikan kepada staf Tata Usaha (TU) yang kemudian akan direkap tiap semester untuk ditulis di buku rapor siswa tiap semester. Cara ini sangatlah rentan dari berbagai macam kesalahan baik kesalahan teknis (technical error), maupun kesalahan manusia (human error). Kesalahan kesalahan ini akan menyebabkan hilangya berkas ataupun rusak. Pada penelitian lain oleh Recky T, yang berjudul Perancangan Sistem Informasi Akademik Sekolah Berbasis Web Studi Kasus Sekolah Menengah Atas Kristen 1 Tomohon Penelitian ini membahas tentang pembuatan Web disalah satu sekolah menengah atas, karena melihat kualitas pengolahan data yang masih manual yaitu masih menggunakan kertas dan pulpen. Dengan menggunakan metodologi Waterfall, perancangan sistem informasi akademik berbasis web ini dapat meningkatkan kualitas pengolahan data akademik di sekolah tersebut. Dengan menggunakan PHP dan dan MySQL. Pada penelitian ini masih ada kekurangan dalam mengimplementasikan aplikasinya dengan tidak adanya fiture untuk melakukan absensi secara sistem sehingga tidak dapat melakukan pengecekan dan report terhadap. 
Penelitian lain oleh Deasy Permatasari dengan judul Perancangan Sistem Informasi Akademik di Smk Pasundan Majalaya Berbasis Web, Informasi mengenai sekolah dapat dengan mudah diakses melalui Web diharapkan dapat memperkenalkan profil SMK Pasundan Majalaya secara luas terhadap masyarakat. Kekurangna dalam penelitian ini pada proses penjadwalaan masih dilakukan dalam proses maual belum dilakukan secara komputerisasi .

\subsection{Hasil Penelitian}

\subsubsection{Perancangan Sistem}

Setelah database terbentuk, maka selanjutnya dilakukan perancangan system yang akan dibuat seperti berikut.

\subsubsection{Use Case Diagram}

1) Use Case Diagram File Master

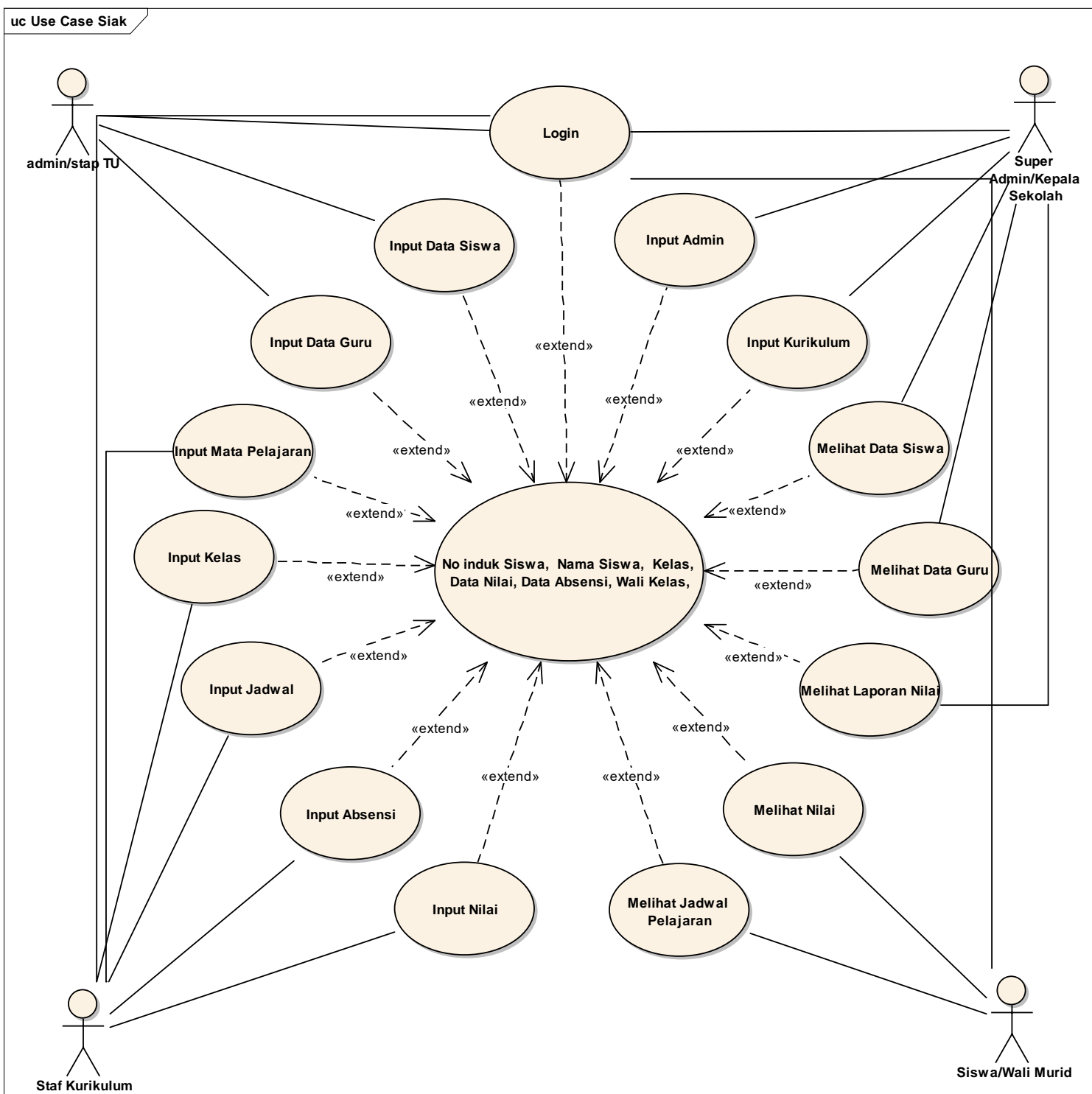

Gambar 4.1 Use Case Diagram File Master 


\subsubsection{Sequance Diagram}

Berikut adalah model sequence diagram sistem akademik yang diusulkan:

1) Sequence Diagram proses Login

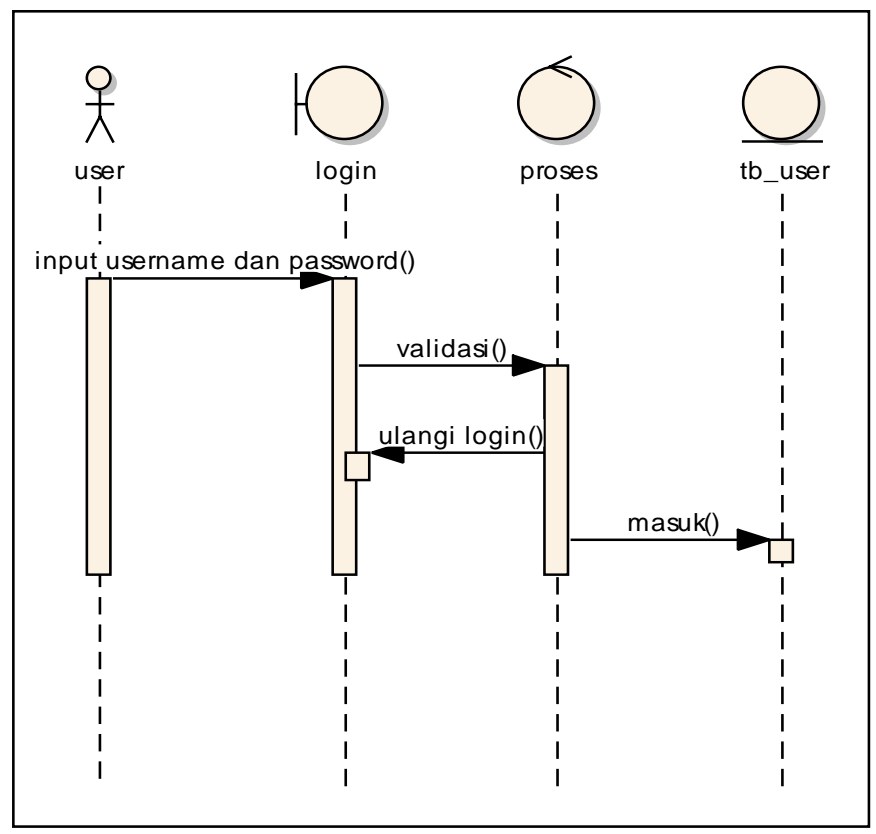

Gambar 4.2 Sequence Diagram Proses Login

2) Sequence Diagram Kelola Data Admin

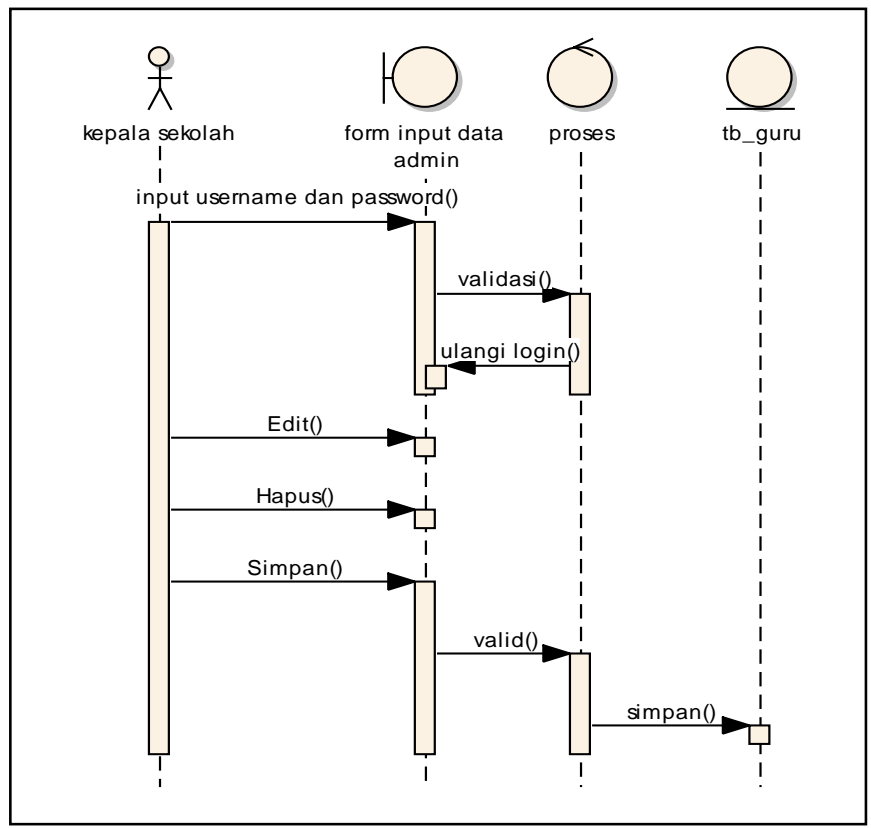

Gambar 4.3 Sequence Diagram Kelola Data Admin 


\subsubsection{Activity Diagram}

Berikut adalah model activity diagram sistem akademik yang diusulkan:

1) Pengolahan Login User

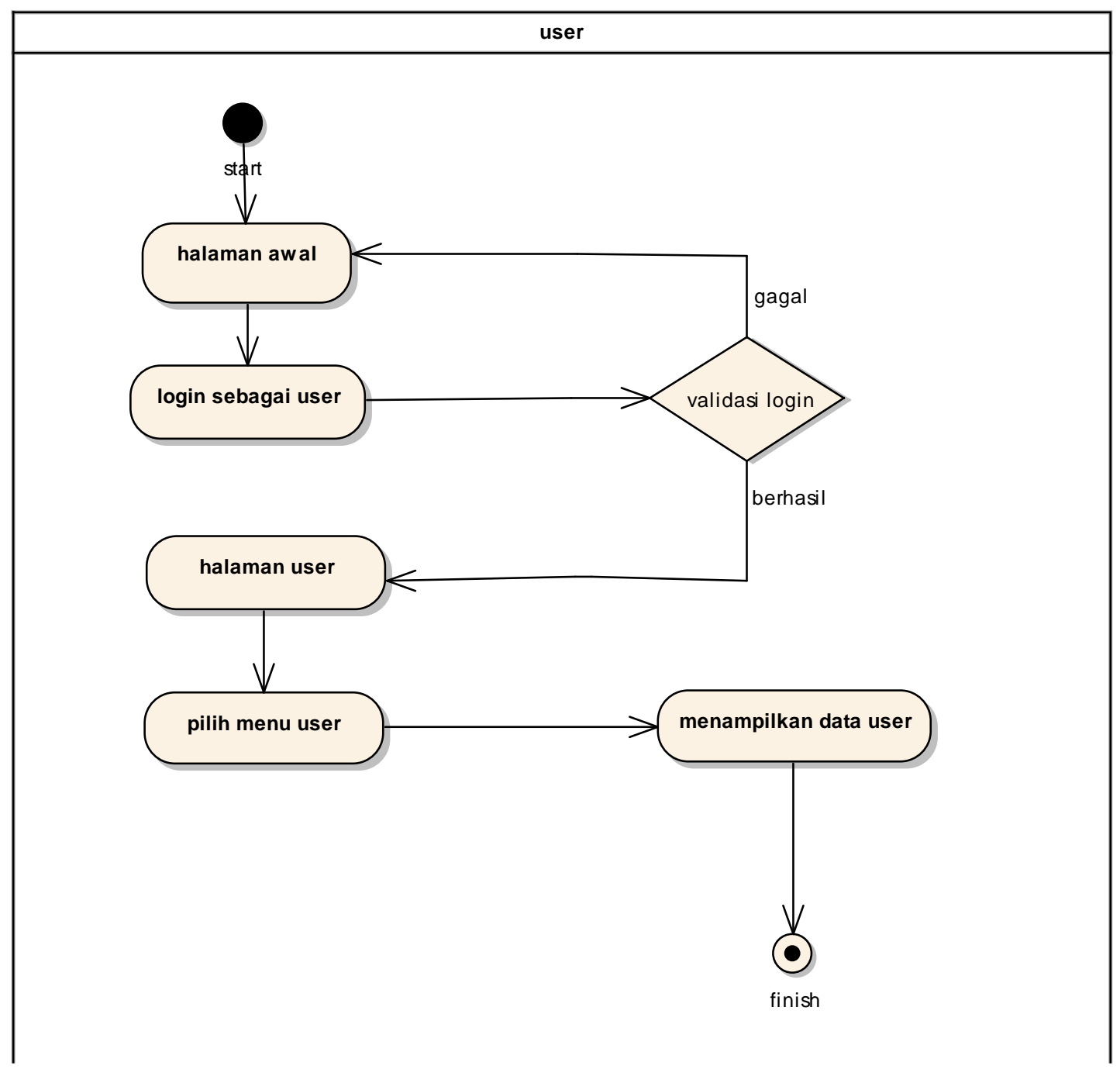

Gambar 4.4 Activity Diagram Login Use 


\subsubsection{Implementasi Tampilan}

1. Tampilan Login

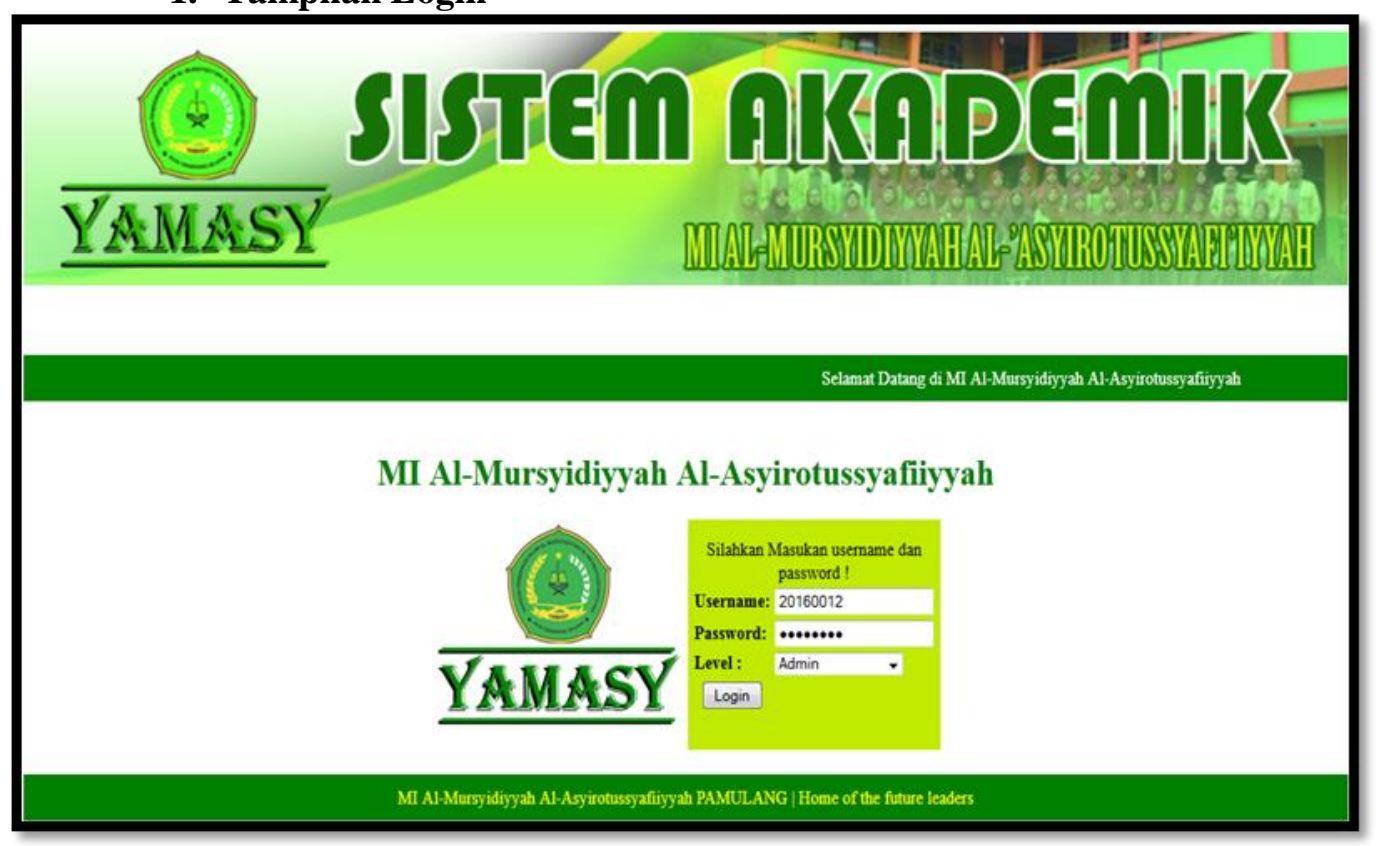

Gambar 4.5 Tampilan Logiin

2. Tampilan Halaman Admin



Gambar 4.6 Tampilan Halaman Admin 


\subsubsection{Rancangan Pengujian}

Pengujian yang dilakukan terhadap aplikasi sistem informasi akademik ini adalah pengujian dengan metode Blackbox. Pengujian dilakukan dengan menjalankan semua fungsi dan fitur yang ada didalam aplikasi ini dan kemudian dilihat apakah hasil dari fungsi-fungsi tersebut sesuai dengan yang diharapkan. Aplikasi dijalankan melalui suatu Web Browser dan mencoba mengakses sistem informasi akademik. Berikut hasil pengujian terhadap aplikasi sistem dapat dilihat pada tabel 4.2.

1) Hasil Pengujian Login

Tabel 4.1 Hasil Pengujian Login

\begin{tabular}{|l|l|l|l|}
\hline Test Case & Prosedur Yang di Jalankan & $\begin{array}{l}\text { Hasil Yang di } \\
\text { Harapkan }\end{array}$ & Hasil \\
\hline Login & $\begin{array}{l}\text { User memasukkan } \\
\text { username dan password kemudian klik } \\
\text { login. }\end{array}$ & $\begin{array}{l}\text { User masuk ke } \\
\text { halaman dashboard }\end{array}$ & Berhasil \\
\hline
\end{tabular}

\section{2) Hasil Pengujian Login Sebagai Admin}

Tabel 4.2 Hasil Pengujian Login Sebagai Admin

\begin{tabular}{|c|c|c|c|}
\hline Test Case & Prosedur Yang di Jalankan & $\begin{array}{l}\text { Hasil Yang di } \\
\text { Harapkan }\end{array}$ & Hasil \\
\hline $\begin{array}{l}\text { Melihat } \\
\text { Biodata }\end{array}$ & Login sebagai Admin pilih menu Biodata & $\begin{array}{l}\text { Menampilkan } \\
\text { Biodata }\end{array}$ & Berhasil \\
\hline $\begin{array}{l}\text { Mengedit } \\
\text { Pasword }\end{array}$ & $\begin{array}{l}\text { Login sebagai Admin pilih menu Biodata, Pilih } \\
\text { edit password kemudian masukan password } \\
\text { baru kemudian simpan }\end{array}$ & Password Berubah & Berhasil \\
\hline $\begin{array}{l}\text { Melihat Data } \\
\text { Siswa }\end{array}$ & Login sebagai Admin pilih menu Siswa & $\begin{array}{l}\text { Menampilkan Data } \\
\text { Siswa }\end{array}$ & Berhasil \\
\hline $\begin{array}{l}\text { Input Data } \\
\text { Siswa }\end{array}$ & $\begin{array}{l}\text { Login sebagai Admin pilih menu Siswa, pilih } \\
\text { Input Data Siswa, Masukan Biodata Siswa } \\
\text { kemudian simpan. }\end{array}$ & $\begin{array}{l}\text { Data Siswa } \\
\text { Bertambah }\end{array}$ & Berhasil \\
\hline $\begin{array}{l}\text { Melihat Data } \\
\text { Guru }\end{array}$ & Login sebagai Admin pilih menu Guru & $\begin{array}{l}\text { Menampilkan Data } \\
\text { Guru }\end{array}$ & Berhasil \\
\hline $\begin{array}{l}\text { Input Data } \\
\text { Guru }\end{array}$ & $\begin{array}{l}\text { Login sebagai Admin pilih menu Guru, pilih } \\
\text { Input Data Guru, Masukan Biodata Guru } \\
\text { kemudian simpan. }\end{array}$ & Data Guru Bertambah & Berhasil \\
\hline Logout & Login sebagai Admin pilih menu Logout & $\begin{array}{l}\text { Menampilkan Menu } \\
\text { Login kembali }\end{array}$ & Berhasil \\
\hline
\end{tabular}


3) Hasil Pengujian Menu Super Admin/Kepala Sekolah

Tabel 4.5 Hasil Pengujian Login Sebagai Super Admin/Kepala Sekolah

\begin{tabular}{|c|c|c|c|}
\hline Test Case & Prosedur Yang di Jalankan & $\begin{array}{l}\text { Hasil Yang di } \\
\text { Harapkan }\end{array}$ & Hasil \\
\hline Melihat Biodata & $\begin{array}{l}\text { Login sebagai Kepala Sekolah pilih } \\
\text { menu Biodata }\end{array}$ & $\begin{array}{l}\text { Menampilkan } \\
\text { Biodata }\end{array}$ & Berhasil \\
\hline Mengedit Pasword & $\begin{array}{l}\text { Login sebagai Kepala Sekolah pilih } \\
\text { menu Biodata, Pilih Edit Password, } \\
\text { masukan password baru, kemudian } \\
\text { Simpan. }\end{array}$ & $\begin{array}{l}\text { Password } \\
\text { Berubah }\end{array}$ & Berhasil \\
\hline Melihat Daftar Admin & $\begin{array}{l}\text { Login sebagai Kepala Sekolah pilih } \\
\text { menu Admin }\end{array}$ & $\begin{array}{l}\text { Menampilkan } \\
\text { Daftar Admin }\end{array}$ & Berhasil \\
\hline Input Admin Baru & $\begin{array}{l}\text { Login sebagai Kepala Sekolah pilih } \\
\text { menu Admin Kemudian Input Admin } \\
\text { masukan biodata Admin kemudian } \\
\text { Simpan. }\end{array}$ & $\begin{array}{l}\text { Admin } \\
\text { Ditambahkan }\end{array}$ & Berhasil \\
\hline $\begin{array}{l}\text { Melihat Daftar } \\
\text { Kurikulum }\end{array}$ & $\begin{array}{l}\text { Login sebagai Kepala Sekolah pilih } \\
\text { menu Kurikulum }\end{array}$ & $\begin{array}{l}\text { Menampilkan } \\
\text { Daftar } \\
\text { Kurikulum }\end{array}$ & Berhasil \\
\hline Input Kurikulum Baru & $\begin{array}{l}\text { Login sebagai Kepala Sekolah pilih } \\
\text { menu Kurikulum Kemudian Input } \\
\text { Kurikulum masukan biodata kurikulum } \\
\text { kemudian Simpan. }\end{array}$ & & \\
\hline Melihat Daftar Siswa & $\begin{array}{l}\text { Login sebagai Kepala Sekolah pilih } \\
\text { menu Siswa. }\end{array}$ & $\begin{array}{l}\text { Menampilkan } \\
\text { Daftar Siswa }\end{array}$ & Berhasil \\
\hline Mencari Nama Siswa & $\begin{array}{l}\text { Login sebagai Kepala Sekolah pilih } \\
\text { menu Siswa kemudian masukkan id } \\
\text { siswa klik Cari. }\end{array}$ & $\begin{array}{l}\text { Menampilkan } \\
\text { Nama Siswa }\end{array}$ & Berhasil \\
\hline Melihat Daftar Guru & $\begin{array}{l}\text { Login sebagai Kepala Sekolah pilih } \\
\text { menu Guru. }\end{array}$ & $\begin{array}{l}\text { Menampilkan } \\
\text { Daftar Guru }\end{array}$ & Berhasil \\
\hline Mencari Nama Guru & $\begin{array}{l}\text { Login sebagai Kepala Sekolah pilih } \\
\text { menu Guru kemudian masukkan id } \\
\text { Guru klik Cari. }\end{array}$ & $\begin{array}{l}\text { Menampilkan } \\
\text { Nama Guru }\end{array}$ & Berhasil \\
\hline $\begin{array}{l}\text { Melihat Laporan Nilai } \\
\text { Siswa }\end{array}$ & $\begin{array}{l}\text { Login sebagai Kepala Sekolah pilih } \\
\text { menu Laporan, masukan id siswa, } \\
\text { Semester dan Tahun Ajaran. }\end{array}$ & $\begin{array}{l}\text { Menampilkan } \\
\text { Laporan Nilai } \\
\text { Siswa }\end{array}$ & Berhasil \\
\hline
\end{tabular}




\begin{tabular}{|l|l|l|l|}
\hline Logout & $\begin{array}{l}\text { Login sebagai Kepala Sekolah pilih } \\
\text { menu Logout. }\end{array}$ & $\begin{array}{l}\text { Menampilkan } \\
\text { Menu Login } \\
\text { kembali }\end{array}$ & Berhasil \\
\hline
\end{tabular}

\section{PENUTUP}

\section{$5.1 \quad$ Kesimpulan}

Dari hasil pembuatan sistem informasi akademik, dan sebagai akhir dari penulisan skripsi, penulis dapat menarik beberapa kesimpulan sebagai berikut :

a. Dengan adanya sistem informasi akademik yang sudah dibuat ini, di harapkan terbentuknya sistem akademik yang dinamis, sederhana dan mudah di gunakan.

b Sistem informasi akademik yang dibuat dapat membantu dan mempercepat proses pencatatan data guru, siswa, kelas, pembuatan jadwal pelajaran dan penilaian menggunakan sistem akademik berbasis web.

c. Dengan adanya sistem ini, pencarian data di harapkan dapat lebih cepat dan akurat

\subsection{Saran}

Sebaik apapun sistem yang dibuat pasti memiliki kekurangan yang perlu untuk dikembangkan, yaitu dengan membuat versi terbaru dari sistem tersebut. Untuk itu dibuatlah penyampaian dalam bentuk saran untuk kesempurnaan sistem ini di masa mendatang.

Adapun saran tersebut adalah sebagai berikut

a. Sistem Informasi Akademik yang dibuat hanya terbatas pada urusan nilai, jadwal, dan absensi. Saran pengembangan: sistem akademik dibuat lebih kompleks seperti pendaftaran siswa baru, penyediaan informasi dan berita terbaru, keuangan, gaji guru, perpustakaan online serta fasilitas e-learning.

b. Tampilan web ini masih sangat sederhana, untuk itu dalam pengembangan diharapkan untuk ditambahkan animasi dan perbaikan tampilan lagi.

\section{DAFTAR PUSTAKA}

1) Al Fatta, Hanif. 2007. Analisis Dan Perancangan Sistem Informasi. Yogyakarta : Andi

2) Arbani, Marizka. 2011. Pengembangan Sistem Informasi Sekolah Berbasis Web (Studi Kasus: MI An-Nizhomiyah Depok). Fakultas Sains Dan Teknologi, Universitas Islam Negeri Syarif Hidayatullah Jakarta

3) Betta, Sidik. 2005. MySQL Untuk Pengguna, Administrasi, Dan Pengembangan Aplikasi Web. Bandung : Informatika

4) Cahyo, Ericko Dwi. 2009. Perancangan Sistem Informasi Berbasis Web Pada SMA Kartika I-1 Medan. Fakultas Matematika Dan Ilmu Pengetahuan Alam, Universitas Sumatera Utara Medan

5) Dawimah. 2010. Aplikasi Pelayanan Informasi Akademik Menggunakan Protokol WAP (Studi Kasus: Madrasah Aliyah Al-Hikmah 2 Brebes). Fakultas Sains Dan Teknologi, Universitas Islam Negeri Syarif Hidayatullah Jakarta

6) Gulo, W. 2007. Metode Penelitian. Jakarta : Grasindo

7) Hariyanto, Bambang. 2004. Sistem Operasi Edisi 3 (tiga). Jakarta : Informatika

8) Jamaliyah. 2011. Sistem Informasi Akademik Berbasis Client Server (Studi Kasus: Madrasah Tsanawiyah AnNizhamiyyah Cileungsi). Fakultas Sains Dan Teknologi, Universitas Islam Negeri Syarif Hidayatullah Jakarta

9) Jogiyanto. 2005. Pengenalan Komputer. Yogyakarta : Andi 
10) Kadir, Abdul. 2003. Pengenalan Sistem Informasi. Yogyakarta: Andi

11) Kendall, Kenneth E; Kendal, Julie E. 2003. Analisis Dan Perancangan Sistem. Jakarta : Indeks

12) Kendall, Kenneth E; Kendal, Julie E. 2008. Analisis Dan Perancangan Sistem Edisi 5 (lima). Jakarta : Indeks

13) Ladjamudin, Al-Bahra Bin. 2005. Analisis dan Desain Sistem Informasi. Yogyakarta : Graha Ilmu

14) McLeod, Raymond; Schell, George. 2004. Sistem Informasi Manajemen Edisi 8 (delapan). Jakarta : Indeks

15) Mulyanto, Agus. 2009. Sistem Informasi Konsep dan Aplikasi. Yogyakarta : Pustaka Pelajar 